\title{
Revisiting the concept of hepatosplenic schistosomiasis and its challenges using traditional and new tools
}

\author{
José Roberto Lambertucci ${ }^{[1]}$
}

[1]. Departamento de Clínica Médica, Faculdade de Medicina, Universidade Federal de Minas Gerais, Belo Horizonte, MG.

\begin{abstract}
Different aspects of hepatosplenic schistosomiasis are revisited here. Manson's schistosomiasis causes periportal fibrosis and portal hypertension in approximately $6 \%$ of infected subjects, usually with preservation of their hepatic function. The assessment of liver involvement is of major importance in determining the prognosis and risk of complications from schistosomiasis, such as upper digestive bleeding secondary to variceal rupture. For many years, the diagnosis of hepatosplenic schistosomiasis and liver fibrosis was made by abdominal palpation and the finding of liver and/or spleen enlargement. However, there is no consensus regarding the clinical parameters of the liver and spleen to be considered in this physical evaluation. For the last three decades, abdominal ultrasound (US) has become the best imaging technique to evaluate liver fibrosis caused by schistosomiasis mansoni. However, US is a subjective procedure and is therefore examiner-dependent. Magnetic resonance imaging (MRI) findings have provided valuable information in addition to ultrasound and clinical examination. The combination of a comprehensive history and physical examination, basic laboratory tests (a stool examination for Schistosoma mansoni eggs and a blood cell count), biomarkers for liver fibrosis/portal hypertension and imaging methods seem to offer the best approach for evaluating patients with this disease. In situations where research is involved or in patients with severe disease, MRI may be considered.
\end{abstract}

Keywords: Hepatosplenic schistosomiasis. Ultrasound. Magnetic resonance imaging.

Thrombocytopenia. Manson's schistosomiasis.

\section{INTRODUCTION}

Every time a new and more precise diagnostic technique is created, changes in previous concepts and definitions are mandatory. History has taught us that scientific progress walks side-by-side with our ability to measure Nature. The word definition originates from the Latin word de+finire, with finire meaning to die or to set limits to (or to demark sharply the outlines or limits of an area or concept). One of the well-known sayings of Socrates, a Greek philosopher, is I only know that I know nothing. He also stated that wisdom is to know the definition of things ${ }^{1}$. The conventional interpretation of this remark is that Socrates' wisdom was limited to an awareness of his own ignorance. Most of us have problems with definitions. For example, when questioned about time, Saint Augustine said he was aware of it but, regrettably, did not know its definition.

The subject of our review naturally has everything to do with definition. The questions we have been called to answer here are of 2 types: I) what is the definition of hepatosplenic schistosomiasis, and II) what are the contributions of imaging techniques and biological markers in diagnosing hepatosplenic schistosomiasis?

Address to: Dr. José Roberto Lambertucci. FM/UFMG. Av. Alfredo Balena 190, 30130-100 Belo Horizonte, MG, Brasil.

Phone: 5531 3337-7781

e-mail: lamber@uai.com.br

Received 16 September 2013

Accepted 22 January 2014

\section{DEFINITION OF HEPATOSPLENIC SCHISTOSOMIASIS}

This complication of schistosomiasis presents pathological, clinical, laboratory and imaging aspects that should help us with its definition.

\section{PATHOLOGICAL DEFINITION OF HEPATOSPLENIC SCHISTOSOMIASIS}

The main lesion in hepatosplenic schistosomiasis is fibrosis in the portal tracts of the liver with pylephlebitis and peripylephlebitis caused by schistosome ova ${ }^{2,3}$. Symmers' pipestem fibrosis is a periportal fibrosis without bridging, nodular formation or significant hepatocellular destruction. It is the result of egg-induced chronic presinusoidal inflammation leading to the deposition of fibrous material and vascular destruction. These fibrotic changes produce a stellate portal fibrosis all along the branching of the portal vein. Within the fibrosed and enlarged portal space, there are partially or totally obstructive vascular lesions (intravascular granulomas, thrombosis, phlebosclerosis and fibrous intimal thickening).

Granulomas around ova can be seen in abundance in the portal spaces. They are smaller than in the early stages of the disease. After cessation of parasitic activity they may disappear, but the fibrosis persists.

In Schistosoma mansoni infections, the major hepatic pathology of egg granulomas results from physical obstruction and tissue compression. Obstruction is presinusoidal in contrast to findings in Laennec's cirrhosis ${ }^{4}$. 
The liver may be enlarged, of normal size or even slightly shrunken; its outer surface is sometimes nodular. Hepatic fibrosis evolves from an excessive accumulation of collagen in the liver 5 .

In most patients with hepatosplenic schistosomiasis, the spleen is increased in size. Splenomegaly results from chronic passive congestion and hyperplasia of the reticuloendothelial system. The microscopic appearance is indistinguishable from that observed in sclero-congestive splenomegalies. The portal blood flow is increased in massive splenomegaly because an enlarged spleen requires a greater blood supply, which in turn increases portal hypertension due to a presinusoidal block ${ }^{6}$.

The problem with pathological definitions is that a liver tissue sample of sufficient size is necessary for a definitive diagnosis, and percutaneous needle liver biopsies may not retrieve enough material for a definitive diagnosis in one-third of cases $^{3,7,8}$.

\section{CLINICAL DEFINITION OF HEPATOSPLENIC SCHISTOSOMIASIS}

There is enlargement of the liver and the spleen in S. mansoni infections, which develops insidiously. After persistent infection and an evolving pathological process, hepatic enlargement is clinically recognized in the second or third decades ${ }^{9,10}$.

In most cases, liver and spleen enlargement develop in parallel. The spleen is usually palpable and, in many cases, massively enlarged; upon examination, it is firm, smooth and non-tender (Table 1) $)^{11-13}$.

Additional symptoms and signs observed in hepatosplenic schistosomiasis are hematemesis, melena, ascites, pallor, ankle edema and collateral periumbilical varices. Symptoms suggesting severe hepatic insufficiency, such as jaundice, spider angiomas, palmar erythema, gynecomastia and altered hair distribution are rarely reported. Death from hepatic failure in S. mansoni infections is rare, with the exception of those cases complicated by hepatitis B or C infections, alcohol abuse or repeated esophagogastric bleeding. These events may lead to decompensated hepatosplenic disease or liver failure (Table 2) ${ }^{13}$.

For many years, the diagnosis of hepatosplenic schistosomiasis and liver fibrosis was confirmed by abdominal palpation and the identification of liver and/or spleen enlargement. However, there is no consensus regarding the clinical parameters of the liver and spleen to be considered in this physical evaluation ${ }^{10,14,15}$.

Hepatomegaly and splenomegaly have no uniform definitions. The limit for the determination of an increase in liver volume remains a disputable issue. Some investigators consider hepatomegaly to be present when the organ exceeds the costal margin by $5 \mathrm{~cm}$ along the sternal line or by $4 \mathrm{~cm}$ along the midclavicular line. Others accept as enlarged a liver palpable $2 \mathrm{~cm}$ below the costal margin or simply a palpable liver, without mentioning if the organ is palpable at rest or during inspiration. Still other investigators attribute more importance to liver characteristics such as a hard consistency, the presence of nodules on the hepatic surface and prominence of the left lobe. A palpable liver has been described in different proportions of
TABLE 1 - Characteristics of compensated hepatosplenic schistosomiasis mansoni.

Higher prevalence between $10-30$ years of age

Apparently healthy

Hepatomegaly and/or splenomegaly

Upper digestive bleeding from esophageal varices

No evidence of liver insufficiency

Retardation of growth and infantilism in children

Laboratory tests

normal liver function test results

hypergammaglobulinemia

anemia, leukopenia and/or thrombocytopenia

high serum levels of hyaluronic acid

low platelet counts $(<140,000)$

Ultrasound

characteristic periportal fibrosis

thickening of the gallbladder wall

splenomegaly

evidence of portal hypertension

Magnetic resonance imaging

enhanced signal in areas with liver fibrosis

delay in the excretion of gadolinium in liver periportal areas

enhanced thickening of the gallbladder wall

clear identification of portal vessels and collaterals

Pathology

moderate inflammatory activity

periportal fibrosis; hepatocytes are preserved

lobular structure of the liver is conserved

the liver may be enlarged or of normal size

the spleen size is increased in most cases

normal people. Riedel's lobe (a tongue-like process occasionally extending downward from the right lobe of the liver laterally to the gallbladder) should also be considered in cases of increased right liver lobe size in schistosomiasis ${ }^{16-19}$.

Regarding splenomegaly, the spleen's palpability would be sufficient for some physicians, whereas others believe that the spleen should be palpable at or beyond the costal border with increased consistency. The definition of consistency or elasticity of an organ is also a problem (i.e., how to standardize soft, medium and hard consistency descriptors to be used by different examiners). Thus, the diagnosis of hepatosplenic schistosomiasis varies according to the different criteria mentioned $^{20-22}$. 
TABLE 2 - Characteristics of decompensated hepatosplenic schistosomiasis mansoni.

Patients $>30$ years of age

Right liver lobe is usually shrunken

Association with other liver injuries (viral hepatitis, alcohol abuse and liver ischemia)

Abdominal scars from previous surgeries

Upper digestive bleeding secondary to ruptured esophageal varices is common

Evidence of liver failure: ascites, jaundice, spider angiomas, palmar erythema, gynecomastia and coma

Emaciation

Low serum albumin, increase in serum bilirubin levels

Portal vein thrombosis is common

Chronic active inflammation with piecemeal necrosis

Focal necrosis or regenerative nodules

\section{ULTRASOUND IN HEPATOSPLENIC SCHISTOSOMIASIS}

For the last three decades, abdominal ultrasound (US) has become the best imaging technique for evaluating the liver fibrosis caused by schistosomiasis mansoni. It is an indirect method for diagnosing and classifying the disease. The US examination of subjects with hepatosplenic schistosomiasis has identified a characteristic pattern of abnormalities quite different from those observed in liver cirrhosis and acute schistosomiasis. The most important findings are echogenic thickening of the walls of the portal vein and its branches, indicative of periportal fibrosis, and echogenic enlargement of the gallbladder wall. However, US is a subjective procedure and is therefore examiner-dependent ${ }^{23-32}$.

In endemic areas, at least four groups of individuals have been identified using the data obtained by abdominal palpation and US examination: 1) a spleen $>13 \mathrm{~cm}$ and liver periportal fibrosis, as confirmed by US; 2) a palpable spleen and spleen $>13 \mathrm{~cm}$, as measured by US; 3 ) a spleen $>13 \mathrm{~cm}$ using US and 4) a palpable spleen ${ }^{15,30}$.

Abdominal ultrasound in acute schistosomiasis is characterized by the findings of hepatomegaly and splenomegaly and the presence of several lymph nodes in the portal system and mesenteric area ${ }^{33-35}$.

\section{MAGNETIC RESONANCE IMAGING IN HEPATOSPLENIC SCHISTOSOMIASIS}

Magnetic resonance imaging (MRI) is primarily a noninvasive medical imaging technique used in radiology to visualize detailed internal structures and limited functioning of the body. MRI provides a much greater contrast between the different soft tissue structures of the body than computed tomography (CT) (Figure 1). Magnetic resonance angiography (MRA) generates a clear picture of the vessels, which may help the surgeon plan in advance the best surgical approach to portal hypertension in schistosomiasis (Figure 2). One advantage of an MRI scan is that it is believed to be harmless to the patient. It uses strong magnetic fields and non-ionizing radiation in the radio frequency range, in contrast to $\mathrm{CT}$ scans and traditional $\mathrm{X}$-rays, which both use ionizing radiation. Contrast agents may be injected intravenously to enhance the appearance of blood vessels, tumors or inflammation ${ }^{36-43}$.

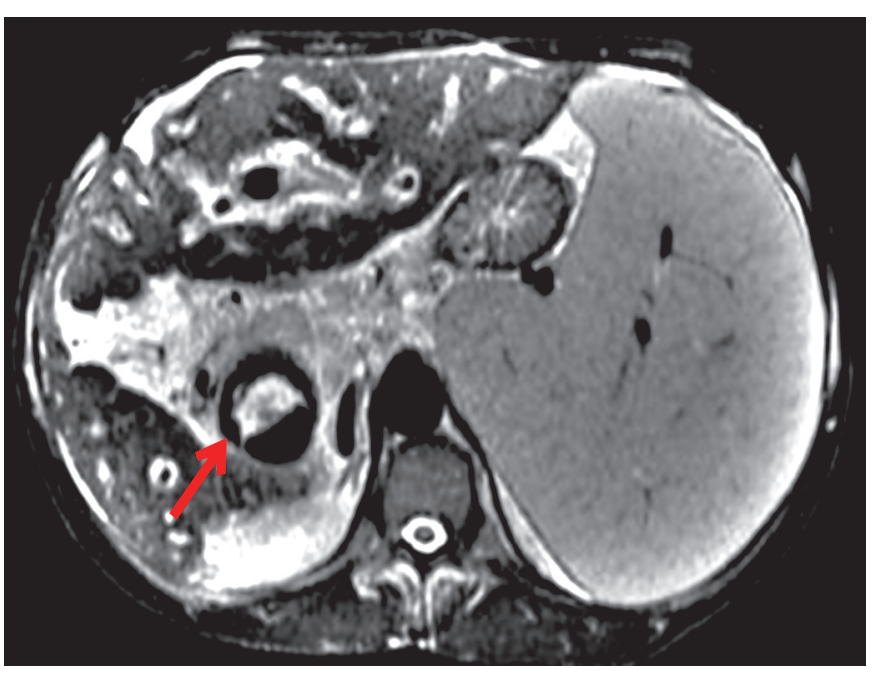

FIGURE 1 - Liver fibrosis in hepatosplenic schistosomiasis (white areas around the vessels). There is a thrombus inside the portal vein (red arrow).

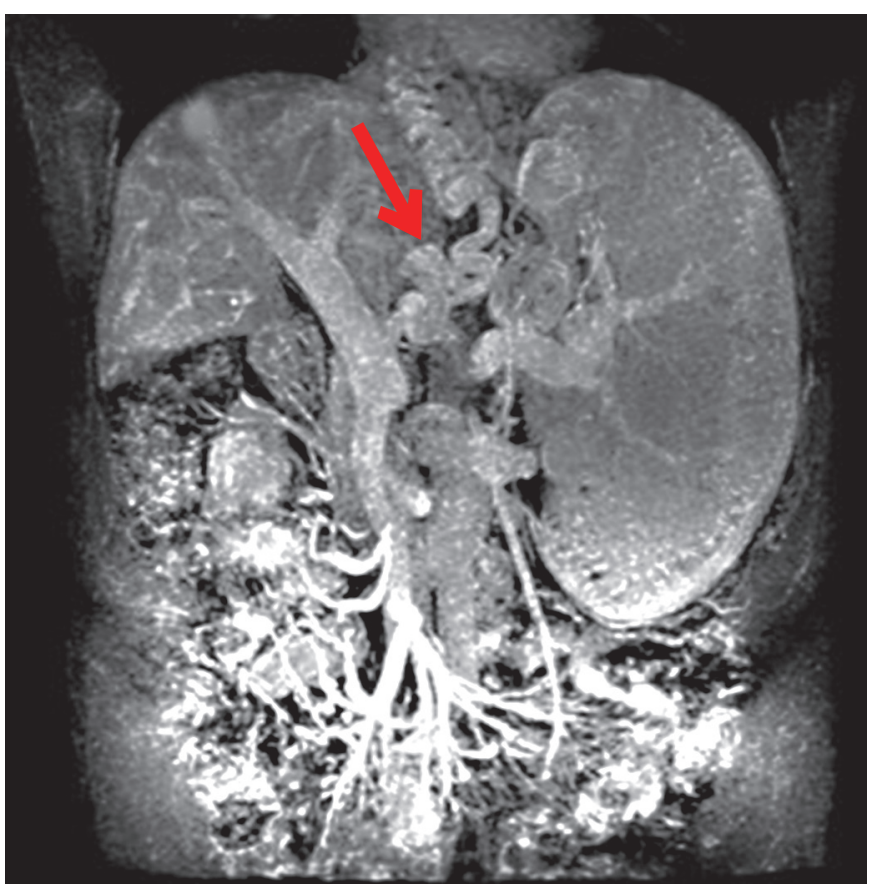

FIGURE 2 - Angioresonance of the abdomen in hepatosplenic schistosomiasis with easy identification of the portal vessels. The red arrow is pointing to a huge collateral vessel (left gastric vein). 


\section{LIVER BIOPSY}

Needle liver biopsy frequently overlooks periportal fibrosis because it retrieves insufficient and fragmented tissue samples with a small number of portal tracts ${ }^{3}$. Wedge liver biopsy taken during surgery for portal hypertension seems to be the best approach for obtaining a good fragment of the liver. Some authors criticize the use of wedge liver biopsy because the fragments come from the periphery of the organ and fibrosis is not expected to be uniformly distributed ${ }^{19}$. Nevertheless, Dusek et al. ${ }^{8}$ stated that a large enough specimen for histological assessment is obtainable only by surgical wedge biopsy and that the specimens are often sufficient to make an accurate diagnosis ${ }^{7,38}$.

\section{INTENSITY OF LIVER FIBROSIS}

Liver fibrosis (LF) intensity is not a definitive surrogate marker for the severity of hepatosplenic schistosomiasis. Our data suggest that the intensity of LF evaluated by imaging techniques or histology is not related, in a significant number of patients, to portal hypertension, and severe portal hypertension has been reported in patients with minimal liver fibrosis ${ }^{13,38}$. The World Health Organization (WHO) grading of liver fibrosis by US should be reevaluated and used carefully in the definition of the severity of hepatosplenic schistosomiasis. Papers published using the WHO classification should also be revised ${ }^{37,38,41}$. The characteristic periportal fibrosis (diagnosed by US, MRI or histology) associated with evidence of portal hypertension (large spleen, esophageal varices and collateral vessels) should be sufficient to define disease severity and indicate surgical intervention, as necessary. We conclude that imaging techniques are reliable for defining the presence of the characteristic schistosomal liver fibrosis in most cases but fail in the grading of the intensity of the fibrosis and the severity of portal hypertension.

\section{SERUM MARKERS OF LIVER FIBROSIS}

Serum markers are of great value not only in patients at risk for a liver biopsy but also as a part of the assessment of patients with hepatosplenic schistosomiasis to avoid invasive methods $^{44,45}$. Fibrosis is a nonspecific response to injuries that implies the synthesis of an extracellular matrix (ECM). The ECM represents a group of macromolecules, including collagens, non-collagen-glycoproteins, matrix-bound growth factors, glycosaminoglycans, proteoglycans and matrix proteins. Hepatic stellate cell activation is the central event leading to hepatic fibrosis. In schistosomiasis, a series of serum markers of fibrosis has already been tested with different results: hyaluronic acid, different types of collagens, cytokines and components of the extracellular matrix, such as YKL- $40^{46,47}$.

Some investigators have suggested that the time has come for the routine use of liver markers of fibrosis to grade its intensity and evaluate the reversal of liver fibrosis after treatment.

\section{COMPLICATIONS OF HEPATOSPLENIC SCHISTOSOMIASIS}

Schistosomal pulmonary hypertension is diagnosed in approximately $10 \%$ of the patients with hepatosplenic schistosomiasis ${ }^{48-51}$; the use of pulmonary vasodilators has greatly improved the survival and quality of life of those patients ${ }^{52-55}$.
Schistosomal glomerulopathy still affects $12-15 \%$ of patients with hepatosplenic schistosomiasis ${ }^{56,57}$. Physicians expected that this complication of the disease would disappear after implementation of the Brazilian program of mass chemotherapy for the control of schistosomiasis. However, advanced forms of hepatosplenic schistosomiasis do not reverse after treatment, and as long as there is hepatosplenic schistosomiasis, schistosomal glomerulonephritis will be found. The prognosis of kidney disease has not improved since its description in the seventies, and the disease will evolve to end stage renal disease.

Neuroschistosomiasis appears to be increasing. In my view, this increased incidence reflects the improvement in its diagnosis with the advent of new imaging techniques, particularly MRI and the progressive awareness of its importance ${ }^{58-62}$.

The association with bacteria (e.g., Salmonella and Staphylococcus aureus) has decreased sharply due to the use of mass chemotherapy, improvements in sanitation and easier access to antibiotics ${ }^{63,64}$.

The association of hepatosplenic schistosomiasis with viral hepatitis B has also decreased, which has been attributed to improvements in the quality of the blood transfused to patients with esophageal bleeding. Additionally, after the advent of sclerotherapy and ligation of esophageal varices, the frequency of severe bleeding has decreased, making blood transfusion dispensable ${ }^{30}$.

Genital schistosomiasis mansoni is also a frequent and neglected aspect of schistosomiasis. Feldmeier et al. estimated that 6 to $27 \%$ of girls and women with intestinal schistosomiasis at least temporarily suffer from pathology induced by eggs sequestered somewhere in their genital organs ${ }^{65}$. In Brazil, this complication of the disease has not been the subject of systematic study, but there have been case reports ${ }^{66-68}$.

\section{THROMBOCYTOPENIA}

The importance of thrombocytopenia has been underestimated in the care of patients with hepatosplenic schistosomiasis mansoni. Low platelet counts are responsible for a major decrease in the quality of life of these patients, particularly because they are living longer ${ }^{69}$.

Surgery (splenectomy) to correct thrombocytopenia has not been considered appropriate for these patients because of the risk of death and other surgical complications (e.g., pneumonia, portal vein thrombosis, abscesses and hospitalization costs). High-risk pregnancy has also been a problem (Figure 3).

Hepatosplenic patients with thrombocytopenia have difficulty finding jobs because they are considered to be sick and cannot work, particularly when the job requires physical exercise $^{70,71}$. Dentists do not treat their gingival problems or remove their teeth because they can bleed excessively. Small surgical interventions are also postponed or avoided (e.g., lymph node biopsies, excision of intestinal polyps, prostate surgery and interventional endoscopy $)^{72,73}$. The use of anti-inflammatory agents or even aspirin is prohibited. The use of anticoagulants is unthinkable. I examined a 76-year-old patient with bilateral cataracts who had been blind for 10 years because surgeons indicated that ophthalmological surgery was contraindicated due 


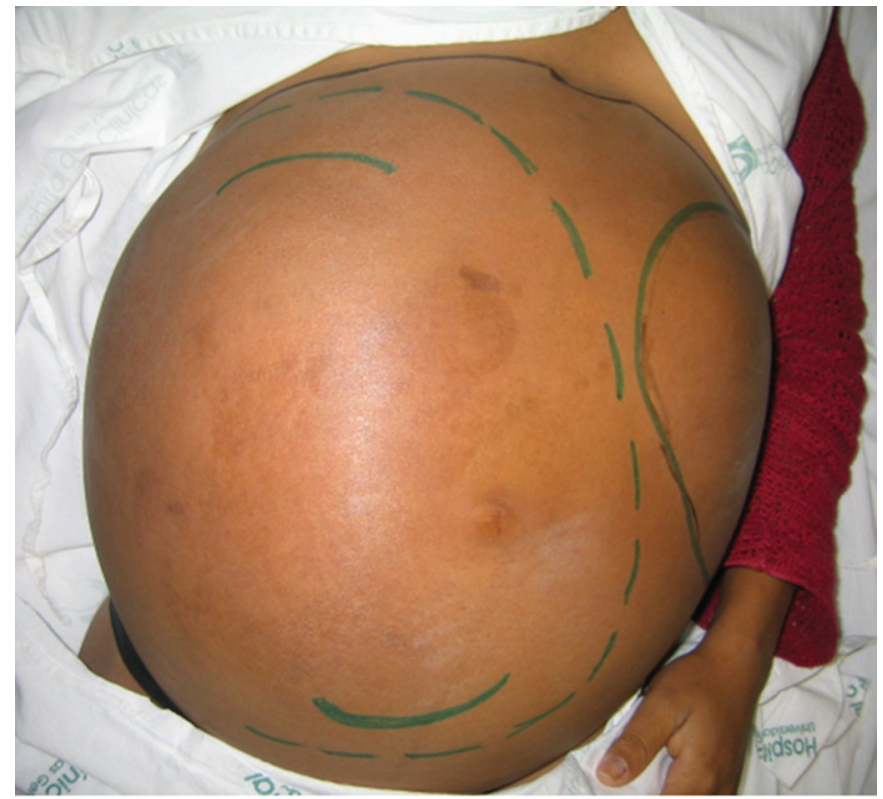

FIGURE 3 - An 8-month-old pregnancy in a middle-aged woman. Note the spleen being pushed by the uterus.

to his low platelet count $\left(40,000 / \mathrm{mm}^{3}\right)$ caused by schistosomal splenomegaly. I insisted that surgery was possible and that I would find a way to resolve his problem. He doubted it because "20" physicians (his number) counseled him against surgery. With some difficulty, I found a colleague who successfully performed the work but was very apprehensive. My argument to convince both the patient and the surgeon was that he was already blind; it was impossible for him to become more blind.

More work is needed to reevaluate the indications for surgical treatment in hepatosplenic schistosomiasis, including the quality of life of such patients.

Thrombocytopenia has been successfully assayed during fieldwork for screening patients with hepatosplenic schistosomiasis in rural areas ${ }^{70}$.

\section{PURE SCHISTOSOMIASIS}

Witnessing scientists and physicians dealing with patients as if they only had schistosomiasis is common. Those patients have been called pure schistosomotics. This definition is a mixture of Platonic delusion with Cartesian reductionism. This confusion is widespread (and applies to other diseases) but is more commonly seen among basic research scientists. In fact, patients with schistosomiasis live in a world with other diseases, such as other helminth infections, tuberculosis, viral hepatitis and other viral infections, acquired immunodeficiency syndrome (AIDS), syphilis, malaria, diabetes mellitus, systemic arterial hypertension, heart failure and pulmonary hypertension. They also take drugs to alleviate their suffering. In endemic areas, schistosomotics are frequently heavy drinkers. Is there really a place in the world for pure schistosomiasis ${ }^{74,75,76-82}$ ?

\section{CONFLICT OF INTEREST}

The author declare that there is no conflict of interest.

\section{FINANCIAL SUPPORT}

This work was partially supported by Conselho Nacional de Desenvolvimento Cientifico e Tecnológico (CNPq) and Fundação de Amparo à Pesquisa do Estado de Minas Gerais (FAPEMIG).

\section{REFERENCES}

1. Kierkegaard S. The concept of irony with constant reference to Socrates. New York, USA: Harper \& Row Publishers; 1965.

2. Symmers WSC. Note on a new form of liver cirrhosis due to the presence of the ova of Bilharzia haematobia. J Pathol Bacteriol 1904; 9:237-239.

3. Bogliolo L. The anatomical picture of the liver in hepatosplenic schistosomiasis mansoni. An Trop Med Parasitol 1957; 51:1-14.

4. Rebouças G. Clinical aspects of hepatosplenic schistosomiasis. A contrast with cirrhosis. Yale J Biol Med 1975; 48:369-376.

5. Andrade ZA. Schistosomal hepatopathy. Mem Inst Oswaldo Cruz 2004; 99 (suppl I):51-57.

6. Warren KS The kinetics of hepatosplenic schistosomiasis. Semin Liver Dis 1984; 4:293-300.

7. Bedossa P, Carrat F. Liver biopsy: the best, not the gold standard. J Hepatol 2009; 50:1-3.

8. Dusek J, Kubasta M, Kodousek R, Kubastova B. Needle biopsy of the liver in shistosomiasis mansoni: the value of histological examination. J Trop Med Hyg 1965; 68:189-195.

9. Lambertucci JR, Rocha RS, Carvalho OS, Katz N. A esquistossomose mansoni em Minas Gerais. Rev Soc Bras Med Trop 1987; 20:47-52.

10. Lambertucci JR. Schistosoma mansoni: pathological and clinical aspects. In: Jordan P, Webbe G, Sturrock RF, editors. Oxon, UK: Cab International Wallingford; 1993. p. 195-235.

11. Elbaz T, Esmat G. Hepatic and intestinal schistosomiasis: review. J Adv Res 2013; 4:445-452.

12. Barsoum RS, Esmat G, Elbaz T. Human schistosomiasis: Clinical perspective. J Adv Res 2013; 4:433-444.

13. Lambertucci JR, Voieta I, Resende V. Slight, moderate and intense Symmers's fibrosis in hepatosplenic schistosomiasis mansoni. Rev Soc Bras Med Trop 2009; 42:611-612.

14. Prata A, Ruiz-Guevara R, Antunes CM, Marinho CC, Queiroz LC, Voieta I, et al. Comparison between clinical and ultrasonographic findings in cases of periportal fibrosis in an endemic area for schistosomiasis mansoni in Brazil. Rev Soc Bras Med Trop 2010; 43:129-134.

15. Lambertucci JR, Cota GF, Pinto-Silva RA, Serufo JC, Gerspacher-Lara R, Costa Drummond S, et al. Hepatosplenic schistosomiasis in field-based studies: a combined clinical and sonographic definition. Mem Inst Oswaldo Cruz 2001; 96 (suppl I):147-150.

16. Kloetzel K. Splenomegaly in schistosomiasis mansoni. Am J Trop Med 1962; 11:472-476.

17. Gerspacher-Lara R, Pinto-Silva RA, Serufo JC, Rayes AA, Drummond SC, Lambertucci JR. Spleen palpation for the evaluation of morbidity due to schistosomiasis mansoni. Mem Inst Oswaldo Cruz 1998; 93 (suppl I): 245-248.

18. Silva LC, Carrilho FJ. Hepatosplenic schistosomiasis: pathophysiology and treatment. Gastroenterol Clin North Am 1992; 21:163-177.

19. Brandt CT, Domingues ALC, Vilela P, Sena A, Marques K, Giusti CF. Histomorphometry of hepatic portal fibrosis in patients with surgical schistosomiasis mansoni. Acta Cir Bras 2002; 17 (suppl I):7-10. 
20. Mies S, Neto OB, Beer Jr A, Baía CE, Alfieri Jr F, Pereira LM, et al. Systemic and hepatic hemodynamics in hepatosplenic Manson's schistosomiasis with and without propranolol. Dig Dis Sci 1997; 42: 751-761.

21. Raia S, Mies S, Alfieri Júnior F. Portal hypertension in mansonic schistosomiasis. World J Surg 1991; 15:176-187.

22. Strauss E, Costa Gayotto LC, Antonelli R, Deperon S, Cabral GL, Raia S. Systemic surgical shunts and splenomegaly as causes of haemolysis in portal hypertension in mansonic schistosomiasis. Evaluation through serum levels of haptoglobin, hemopexin and bilirubins. J Hepatol 1986; 2:340-350.

23. Abdel-Wahab MF, Esmat G, Milad M, Abdel-Razek S, Strickland GT. Characteristic sonographic pattern of schistosomal hepatic fibrosis. Am J Trop Med Hyg 1989; 40:72-76.

24. Hatz C. Use of ultrasound. In: Jordan P, Webbe G, Sturrock RF, editors. Oxon, UK: Cab International Wallingford; 1993. p. 305-329.

25. Pinto-Silva RA, Queiroz LC, Azeredo LM, Silva LC, Lambertucci JR. Ultrasound in schistosomiasis mansoni. Mem Inst Oswaldo Cruz 2010; 105:479-484.

26. Richter J, Domingues AL, Barata CH, Prata AR, Lambertucci JR. Report of the second satellite symposium on ultrasound in schistosomiasis. Mem Inst Oswaldo Cruz 2001; 96 (suppl I):151-156.

27. Prata A, Andrade ZA. Fibrose hepática de Symmers sem esplenomegalia. Hospital 1963; 63:617-623.

28. Petroianu A. Tratamento cirúrgico da hipertensão porta na esquistossomose mansoni. Rev Soc Bras Med Trop 2003; 36:253-265.

29. Homeida MA, Abdel-Gadir AF, Cheever AW, Bennett JL, Arbab BMO, Ibrahim SZ, et al. Diagnosis of pathologically confirmed Symmers' periportal fibrosis by ultrasonography: a prospective blinded study. Am J Trop Med Hyg 1988; 38:86-91.

30. Lambertucci JR, Serufo JC, Gerspacher-Lara R, Rayes AA, Teixeira R, Nobre V, Antunes CM. Schistosoma mansoni: assessment of morbidity before and after control. Acta Trop 2000; 77:101-109.

31. Cota GF, Pinto-Silva RA, Antunes CM, Lambertucci JR. Ultrasound and clinical investigation of hepatosplenic schistosomiasis: evaluation of splenomegaly and liver fibrosis four years after mass chemotherapy with oxamniquine. Am J Trop Med Hyg 2006; 74:103-107.

32. Lambertucci JR, Gerspacher-Lara R, Pinto-Silva RA, Barbosa MM, Teixeira R, Barbosa HF, et al. The Queixadinha Project: morbidity and control of schistosomiasis in an endemic area in the northeast of Minas Gerais, Brazil. Rev Soc Bras Med Trop 1996; 29:127-135.

33. Lambertucci JR. Acute schistosomiasis: clinical, diagnostic and therapeutic features. Rev Inst Med Trop Sao Paulo 1993; 35:399-404.

34. Lambertucci JR. Acute schistosomiasis mansoni: revisited and reconsidered. Mem Inst Oswaldo Cruz 2010; 105:422-435.

35. Lambertucci JR, Drummond SC, Voieta I, Queiróz LC, Pereira PP, Chaves BA, et al. An outbreak of acute Schistosoma mansoni Schistosomiasis in a nonendemic area of Brazil: a report on 50 cases, including 5 with severe clinical manifestations. Clin Infect Dis 2013; 57:e1-e6.

36. Silva LC, Andrade LM, Paula IB, Queiroz LC, Antunes CM, Lambertucci JR. Ultrasound and magnetic resonance imaging findings in schistosomiasis mansoni: expanded gallbladder fossa and fatty hilum signs. Rev Soc Bras Med Trop 2012; 45:500-504.

37. Silva LC, Pereira AC, Queiroz LC, Andrade LM, Antunes CM, Lambertucci JR. Disagreement between ultrasound and magnetic resonance imaging in the identification of schistosomal periportal fibrosis. Mem Inst Oswaldo Cruz 2006; 101(suppl I):279-282.

38. Voieta I, Queiroz LC, Andrade LM, Silva LC, Fontes VF, Barbosa Jr A, et al. Imaging techniques and histology in the evaluation of liver fibrosis in hepatosplenic schistosomiasis mansoni in Brazil: a comparative study. Mem Inst Oswaldo Cruz 2010; 105:414-421.

39. Voieta I, Andrade LM, Lambertucci JR. Magnetic resonance of the liver in acute schistosomiasis. Rev Soc Bras Med Trop 2011; 44:403.

40. Lambertucci JR, Silva LC, Andrade LM, Queiroz LC, Carvalho VT, Voieta I, et al. Imaging techniques in the evaluation of morbidity in schistosomiasis mansoni. Acta Trop 2008; 108:209-217.
41. Silva LC, Andrade LM, Queiroz LC, Voieta I, Azeredo LM, Antunes CM, Lambertucci JR. Schistosoma mansoni: magnetic resonance analysis of liver fibrosis according to WHO patterns for ultrasound assessment of schistosomiasis-related morbidity. Mem Inst Oswaldo Cruz 2010; 105:467-470.

42. Lambertucci JR, Silva LC, Andrade LM, Queiroz LC, Pinto-Silva RA. Magnetic resonance imaging and ultrasound in hepatosplenic schistosomiasis mansoni. Rev Soc Bras Med Trop 2004; 37:333-337.

43. Bezerra AS, D'Ippolito G, Caldana RP, Cecin AO, Ahmed M, Szejnfeld J. Chronic hepatosplenic schistosomiasis mansoni: magnetic resonance imaging and magnetic resonance angiography findings. Acta Radiol 2007; 48:125-134.

44. Grigorescu M. Noninvasive biochemical markers of liver fibrosis. J Gastrointestin Liver Dis 2006; 15:149-159.

45. Liu T, Wang X, Karsdal MA, Leeming DJ, Genovese F. Molecular serum markers of liver fibrosis. Biomark Insights 2012; 7:105-117.

46. Marinho CC, Bretas T, Voieta I, Queiroz LC, Ruiz-Guevara R, Teixeira AL, et al. Serum hyaluronan and collagen IV as non-invasive markers of liver fibrosis in patients from an endemic area for schistosomiasis mansoni: a field-based study in Brazil. Mem Inst Oswaldo Cruz 2010; 105:471-478.

47. Pereira TA, Xie G, Choi SS, Syn WK, Voieta I, Lu J, et al. Macrophagederived Hedgehog ligands promotes fibrogenic and angiogenic responses in human schistosomiasis mansoni. Liver Int 2013; 33:149-161.

48. Barbosa MM, Lamounier JA, Oliveira EC, Souza MV, Marques DS, Silva AA, et al. Pulmonary hypertension in schistosomiasis mansoni. Trans R Soc Trop Med Hyg 1996; 90:663-665.

49. Butrous G, Ghofrani HA, Grimminger F. Pulmonary vascular disease in the developing world. Circulation 2008; 118:1758-1766.

50. Lambertucci JR, Prata PH, Voieta I. Left recurrent laryngeal palsy (Ortner's syndrome) in schistosomal pulmonary hypertension. Rev Soc Bras Med Trop 2010; 43:608.

51. Carvalho VT, Barbosa MM, Nunes MC, Cardoso YS, Sá Filho IM, Oliveira FR, et al. Early right cardiac dysfunction in patients with schistosomiasis mansoni. Echocardiography 2011; 28:261-267.

52. Lambertucci JR, Carvalho VT, Silva LC. Pulmonary hypertension in schistosomiasis mansoni. Rev Soc Bras Med Trop 2006; 39:295-296.

53. Morrell NW, Archer SL, Defelice A, Evans S, Fiszman M, Martin T, et al. Anticipated classes of new medications and molecular targets for pulmonar arterial hypertension. Pulm Circ 2013; 3:226-244.

54. Tackett KL, Stajich GV. Combination pharmacotherapy in the treatment of pulmonary arterial hypertension: continuing education article. J Pharm Pract 2013; 26:18-28.

55. Buckley MS, Staib RL, Wicks LM. Combination therapy in the management of pulmonary arterial hypertension. Int J Clin Pract Suppl 2013; 179:13-23.

56. Rodrigues VL, Otoni A, Voieta I, Antunes CM, Lambertucci JR. Glomerulonephritis in schistosomiasis mansoni: a time to reappraise. Rev Soc Bras Med Trop 2010; 43:638-642.

57. Lambertucci JR, Godoy P, Neves J, Bambirra EA, Ferreira MD Glomerulonephritis in Salmonella-Schistosoma mansoni association. Am J Trop Med Hyg 1988; 38:97-102.

58. Braga BP, Costa Junior LB, Lambertucci JR. Magnetic resonance imaging of cerebellar schistosomiasis mansoni. Rev Soc Bras Med Trop 2003; 36:635-636.

59. Manzella A, Borba-Filho P, Brandt CT, Oliveira K. Brain magnetic resonance imaging findings in young patients with hepatosplenic schistosomiasis mansoni without overt symptoms. Am J Trop Med Hyg 2012; 86:982-987.

60. Felipe L, Gonçalves DU, Tavares MC, Sousa-Pereira SR, Antunes CM, Lambertucci JR. Vestibular-evoked myogenic potential (VEMP) in the evaluation of schistosomal myeloradiculopathy. Am J Trop Med Hyg 2009; 81:551-554.

61. Lambertucci JR, Silva LC, Amaral RS. Guidelines for the diagnosis and treatment of schistosomal myeloradiculopathy. Rev Soc Bras Med Trop 2007; 40:574-581. 
62. Vale TC, Sousa-Pereira SR, Ribas JG, Lambertucci JR. Neuroschistosomiasis mansoni: literature review and guidelines. Neurologist 2012; 18:333-342.

63. Lambertucci JR, Teixeira R, Navarro MM, Coelho PM, Ferreira MD. Liver abscess and schistosomiasis. A new association. Rev Soc Bras Med Trop 1990; 23:239-240.

64. Lambertucci JR, Rayes AA, Serufo JC, Nobre V. Pyogenic abscesses and parasitic diseases. Rev Inst Med Trop Sao Paulo 2001; 43:67-74.

65. Feldmeier H, Daccal RC, Martins MJ, Soares V, Martins R. Genital manifestations of schistosomiasis mansoni in women: important but neglected. Mem Inst Oswaldo Cruz 1998; 93 (suppl I):127-133.

66. Lambertucci JR, Villamil QT, Savi D, Dias IC. Genital schistosomiasis mansoni: tubal tumor and parietal peritoneum involvement diagnosed during laparoscopy. Rev Soc Bras Med Trop 2009; 42:583-586.

67. Lambertucci JR, Voieta I, De Brot M. Vulvar schistosomiasis mansoni. Rev Soc Bras Med Trop 2008; 41:435-436.

68. Lambertucci JR, Voieta I, Barbosa AJ. Schistosomiasis mansoni of the prostate. Rev Soc Bras Med Trop 2006; 39:233-234.

69. Souza MR, Toledo CF, Borges DR. Thrombocytemia as a predictor of portal hypertension in schistosomiasis. Dig Dis Sci 2000; 45:1964-1970.

70. Lambertucci JR, Silva LC, Antunes CM. Aspartate aminotransferase to platelet ratio index and blood platelet count are good markers for fibrosis evaluation in schistosomiasis mansoni. Rev Soc Bras Med Trop 2007; 40:599.

71. Lambertucci JR, Duani H, Prata PH, Voieta I. Pseudothrombocytopenia in schistosomiasis mansoni. Rev Soc Bras Med Trop 2011; 44:792.

72. Maurizio R, Eugenio C, Roberto PR. Results of sclerotherapy for bleeding esophageal varices in patients with schistosomal liver disease. A retrospective study. Hepatogastroenterology 2000; 47:424-428.

73. Gasim B, Fedail SS, Musaad AM, Salih SM, Ibn-Ouf M. Endoscopic sclerotherapy for bleeding oesophageal varices: experience in Sudan. Trop Gastroenterol 2002; 23:107-109.
74. Pirajá da Silva MA. Contribuição para o estudo da schistosomíase na Bahia. Brasil Médico 1908; 29:281-283.

75. Prata A. Influence of the host-related factors in the development of the hepatosplenic schistosomiasis mansoni. Mem Inst Oswaldo Cruz 1992; 87:369-376.

76. Avila RE, Batista TS, Xavier MA, Nogueira AM, Lambertucci JR. Schistosomiasis mansoni and severe gastrointestinal cytomegalovirus disease in a patient with acquired immunodeficiency syndrome. Rev Soc Bras Med Trop 2006; 39:379-382.

77. Nobre V, Braga E, Rayes A, Serufo JC, Godoy P, Nunes N, et al. Opportunistic infections in patients with AIDS admitted to a University Hospital of the Southeast of Brazil. Rev Inst Med Trop Sao Paulo 2003; 45:69-74.

78. Lambertucci JR, Rayes AA, Nunes F, Landazuri-Palacios JE, Nobre V. Fever of undetermined origin in patients with the acquired immunodeficiency syndrome in Brazil: report on 55 cases. Rev Inst Med Trop Sao Paulo 1999; 41:27-32.

79. Lambertucci JR, Rayes AA, Serufo JC, Gerspacher-Lara R, Brasileiro Filho G, Teixeira R, et al. Schistosomiasis and associated infections. Mem Inst Oswaldo Cruz 1998; 93 (suppl I):135-139.

80. Lambertucci JR, Rayes AA, Gerspacher-Lara R. Salmonella-S. mansoni association in patients with acquired immunodeficiency syndrome. Rev Inst Med Trop Sao Paulo 1998; 40:233-235.

81. Serufo JC, Antunes CM, Pinto-Silva RA, Gerspacher-Lara R, Rayes AA, Drummond SC, et al. Chronic carriers of hepatitis B surface antigen in an endemic area for schistosomiasis mansoni in Brazil. Mem Inst Oswaldo Cruz 1998; 93 (suppl I):249-253.

82. Abdel-Rahman M, El-Sayed M, El Raziky M, Elsharkawy A, El-Akel W, et al. Coinfection with hepatitis $\mathrm{C}$ virus and schistosomiasis: fibrosis and treatment response. World J Gastroenterol 2013; 19:2691-2696. 